\title{
EXPERIMENTAL PATHOLOGY AND THE ORIGINS OF TISSUE CULTURE: LEO LOEB'S CONTRIBUTION
}

\author{
by
}

\author{
JAN A. WITKOWSKI*
}

\section{INTRODUCTION}

The development of new fields of study in scientific research frequently depends on the advance of new techniques, and such techniques can revolutionize research in already established fields. Tissue culture is an excellent example of such a technical revolution. An editorial published in 1910 in the Journal of the American Medical Association commented that "it lays bare practically a whole new field for experimental attack on many of the fundamental problems in biology and medical science". 1 Only four years later, a review discussed the applications of tissue culture in studies on cell morphology and differentiation, cancer, bacteriology, virology, immunology, radiobiology, and toxicology. ${ }^{2}$

But even such a revolutionary technique as tissue culture has a long history in which the principles of the technique were recognized and various partially successful attempts were made. Harrison's own experiments were part of a long research programme on nerve development in embryogenesis, and Oppenheimer has shown how these experiments were derived from the practices of experimental embryology and in particular from the embryo transplantation experiments of Born. ${ }^{3}$ Nor was Harrison the first to put cells or fragments of tissues or embryos in vitro, and various earlier workers achieved varying degrees of success. Oppenheimer and Rubin have listed a total of nineteen such investigations between 1855 and 1906, and, in view of Harrison's background, it is interesting to note that approximately one-half of these earlier, pioneering attempts were also "embryological"; the remainder may be described as lying within the field of pathology. ${ }^{4}$ Like embryology, pathology had

*Jan A. Witkowski, PhD, Muscle Research Centre, Department of Paediatrics, Royal Postgraduate Medical School, London W12 0HS.

1 [Anonymous], 'Growing animal tissues outside of the body', J. Am. Med. Assoc., 1911, 56: 1722-1723.

${ }^{2} \mathrm{H}$. F. Smyth, 'The cultivation of tissue cells in vitro and its practical application', ibid., 1914, 62: 1377-1381.

3 J. M. Oppenheimer, 'Embryological concepts in the twentieth century', Survey of Biological Progress, 1957, 3: 1-46; idem, 'Ross Harrison's contributions to experimental embryology', Bull. Hist. Med., 1966, 40: 525-543; idem, 'Historical relationships between tissue culture and transplantation experiments', Trans. Stud. Coll. Physns. Phila., 1971, 39: 26-33.

' J. M. Oppenheimer, 'Taking things apart and putting them together again', Bull. Hist. Med., 1978, 52: 149-161; L. Rubin, 'Leo Loeb's role in the development of tissue culture', Clio Medica, 1977, 12: 33-56, note 2, p. 49. This listing is hardly likely to be complete, and as Oppenheimer remarked: "It often seems to me that each time I read about anything I come across something new in this area." (Op. cit., p. 150.) 


\section{Jan A. Witkowski}

developed a strong experimental bias, ${ }^{5}$ and Virchow, building on the work of histologists such as Müller and Henle, had firmly established the cell as the proper concern of the pathologist. ${ }^{6}$

Rubin has drawn attention to parallels between the theories and techniques of experimental pathology and experimental embryology and has suggested that pathology was a second pathway leading to tissue culture. In particular, he referred to the embryological basis of Cohnheim's and Ribbert's theories on the origin of the cancer cell and to the techniques of transplantation used in both pathology and embryology. Rubin used the work of Leo Loeb (1869-1959) to illustrate this thesis and he concluded that Loeb's work was of "undeniable significance for defining many of the conditions for in vitro growth", " and that pathology and embryology were "major avenues" to tissue culture.

However, an examination of contemporary sources shows that those engaged in tissue culture research after 1910 would not have agreed with Rubin. On the contrary, these workers either disregarded or dismissed Loeb's in vitro research and referred only to Harrison. I shall re-examine Rubin's suggestion that experimental pathology was a major factor in the development of tissue culture by comparing the roles of experimental pathology (exemplified by Loeb) and experimental embryology (exemplified by Harrison). I shall pay particular attention to the experimental designs and techniques used by Loeb and Harrison, and their relationship to tissue culture proper. I shall comment on the similarities in their methods, and then discuss why, despite these similarities, it was Harrison and not Loeb who came to be regarded as the founder of tissue culture.

\section{THE BACKGROUND TO LOEB'S EARLY WORK}

In 1958, one year before he died, Loeb published an autobiographical sketch in which he reviewed the principal interests of his scientific career. Chief among these were "the growth processes of tissues in general and tumors in particular", and in both cases he "considered the two factors involved in growth, namely, cell multiplication and cell movements".9 Goodpasture wrote that these interests were present from the beginning of Loeb's career, and emphasized that the "circumstances of his initial environment ... made a lasting impression upon the direction and thread of his thought, inquiring and developing insight". ${ }^{10}$ It is important to consider Loeb's early

\footnotetext{
'E. R. Long, A history of experimental pathology, Baltimore, Williams \& Wilkins, 1928; for a contemporary account of the new experimental embryology see E. S. Russell, Form and function, London, John Murray, 1916, pp. 302-334; Oppenheimer (1957), op. cit., note 3 above.

- $\mathrm{R}$. Virchow, Die Cellularpathologie in ihrer Begründung auf physiologische und pathologische Gewebelehre, Berlin, A. Hirschwald, 1858; English translation by F. Chance, Cellular pathology as based upon physiological and pathological histology, London, Churchill, 1860; W. H. McMenemy, 'Cellular pathology, with special reference to the influence of Virchow's teachings on medical thought and practice', in F. N. L. Poynter (editor), Medicine and science in the 1860s, London, Wellcome Institute of the History of Medicine, 1968, pp. 13-43.

'Rubin, op. cit., note 4 above, p. 33.

Ibid, p. 34.

'L. Loeb, ‘Autobiographical notes', Pers. Biol. Med., 1958, 2: 1-23, p. 11.

${ }^{10}$ E. W. Goodpasture, 'Leo Loeb', Biogr. Mem. Natl. Acad. Sci., 1961, 35: 205-219, p. 217. Other biographies of Loeb are: H. T. Blumenthal, 'Leo Loeb, experimental pathologist and humanitarian',
} 


\section{Experimental pathology and the origins of tissue culture}

scientific environment because the theories on the aetiology of cancer current when Loeb began his research career illustrate clearly the links between this branch of experimental pathology and experimental embryology.

In 1895, Loeb's research career began in Hugo Ribbert's Institute of Pathology at the University of Zurich where he undertook a research project on the transplantation of skin between the white and black pigmented areas of the same guinea pig. Although Loeb did not discuss the background of this project, it was probably based on Ribbert's "tissue tension" theory for the origin of cancers that Ribbert published in the year Loeb joined the Institute.

Ribbert's theory was one of a number that came under the general title of "cell autonomy", a group of theories that Ewing considered "the product of the best thought on the nature of tumors ...".11 The principal feature of this group of theories is that cancers arise when cells are disturbed in their relationship with their neighbours, and they thus escape from the growth controls and restraints that normally act upon them in tissues.

The first major statement of a theory incorporating this idea was the "embryonic rests" theory of Cohnheim. ${ }^{12}$ Cohnheim proposed that there was an excess production of cells during embryogenesis and that these cells retained their potential for embryonic growth into adult life. If these "embryonic rests" became activated in the adult, they began to grow and formed cancers. Cohnheim was not clear on what brought about this activation and there was no data to support his assertion that embryonic cells persisted into adult life and were distributed throughout all tissues. ${ }^{13}$

Ribbert ${ }^{14}$ attempted to modify Cohnheim's theory to take account of these criticisms by discarding Cohnheim's assertion that only embryonic cells could give rise to cancers. Instead, he suggested that all adult cells were capable of division but that their proliferative activity is controlled by "tissue tension". Ribbert originally envisaged that actual physical separation of cells from their surroundings was necessary before they could escape the controlling effects of tissue tension, but he later suggested that "physiological separation" of tissue elements was sufficient.

A fully developed statement of the theory of cell autonomy was made by Adami in 1907. Adami emphasized the relationship between cell differentiation and cell multiplication, and suggested that these were so different that they "... are obviously to a large extent incompatible". ${ }^{15}$ Tissue tension was responsible for the maintenance of

Science, 1960, 131: 907-908; P. A. Shaffer, 'Biographical notes on Dr. Leo Loeb', Arch. Path., 1950, 50: 661-675. The latter includes an extensive bibliography of Loeb's writings.

"J. Ewing, 'Cancer problems', Harvey Lect., 1907-1908: 34-88, p. 47. For other reviews of cancer research at the turn of the century see W. H. Woglom, Studies in cancer and allied subjects, New York, Columbia University Press, 1913. Comprehensive discussions and bibliographies will be found in V. A. Triolo, 'Nineteenth century foundations of cancer research: origins of experimental research', Cancer Res., 1964, 24: 4-27; idem, 'Nineteenth century foundations of cancer research: advances in tumor pathology, nomenclature and theories of oncogenesis', ibid., 1965, 25: 75-106.

$12 \mathrm{~J}$. Cohnheim, Geschwulste. Vorlesungen über allgemeine Pathologie, 2 vols., Berlin, Hirschwald, 1877-1880; Triolo (1964), op. cit., note 11 above, pp. 94-95; Woglom, op. cit., note 11 above, pp. 8-10.

${ }^{13}$ Ewing, op. cit., note 11 above, pp. 49-50.

${ }^{14}$ M. W. H. Ribbert, Das pathologische Wachstum der Gewebe bei der Hypertrophie, Regeneration. Entzündung und Geschwulstbildung, Bonn, Cohen, 1896; Triolo (1964), op. cit., note 11 above, pp. 95-96.

15 J. G. Adami, 'The causation of cancerous and other growths', Br. med. J., 1901, i: 621-628, p. 627. 


\section{Jan A. Witkowski}

the differentiated state, and if this was disturbed then energies formerly used for the differentiated functions of the cell became available for cell division.

The importance of embryological concepts in the theory of cell autonomy is clear. Cohnheim's theory depended on the proliferative capabilities of embryonic cells, Ribbert referred to the regenerative capabilities of adult tissues, and Adami believed an imbalance between differentiation and proliferation to be critical in initiating a cancer. Ewing, in his discussion of tissue tension, drew heavily on embryological concepts and data. He recognized four elements responsible for the maintenance of tissue tension, and of these "the most important element ... is that designated organization". ${ }^{16}$ His discussion of tissue tension and organization was in terms of regeneration of normal tissues, and his source was T. H. Morgan's Regeneration. ${ }^{17}$ Morgan at this time discussed the control of regeneration by "organization" and a system of tensions, ${ }^{18}$ but Ewing distinguished cell proliferation during regeneration from that in tumour growth by virtue of the former having a purpose, repair of the organism. But "experimental morphology has so far signally failed to elucidate the reason for the loss of organization in tumors", and Ewing went on to consider studies of cell behaviour during development and regeneration, especially the views of Weigert and Roux on differentiation. ${ }^{19}$

It is clear that at the turn of the nineteenth century, cancer research drew heavily on experimental embryology for its theoretical framework. This was the theoretical background to Loeb's work, but a study of his experimental methods also reveals close affinities between the techniques of experimental pathology and experimental embryology.

\section{LOEB'S RESEARCH $1897-1910$}

In 1897, Loeb emigrated to the USA, to Chicago where his brother Jaques Loeb ${ }^{20}$ was professor of physiology. Here he continued his research, turning to the behaviour of epithelial cells during wound repair. The first results of these experiments were published in 1898, together with details of the skin transplantation studies that formed his MD thesis.

Loeb emphasized the importance of epithelial cell migration during wound healing and drew a parallel between this cell behaviour and that in the development of a tumour: "... growth of the epithelium in carcinomata of the skin shows some resemblances to the migrating epithelium produced by injuring the normal skin". ${ }^{21}$ It

\footnotetext{
${ }^{16}$ Ewing, op. cit., note 11 above, p. 54.

17 T. H. Morgan, Regeneration, New York, Macmillan, 1901.

18 Ibid. Morgan's use of a system of "tensions" to explain the control of regeneration (pp. 271-276) has a number of similarities to Ribbert's ideas on the control of cell growth by tissue tension. Morgan's discussion of the role of "organization" in developmental phenomena is interesting for its firm rejection of the teleological overtones given to the term "organization" by Driesch (pp. 277-292). For a discussion of Morgan's approach to experimental embryology and particularly his relationship with Hans Driesch see G. E. Allen, Thomas Hunt Morgan - the man and his science, Princeton University Press, 1978.

19 Ewing, op. cit., note 11 above, pp. 56-61.

${ }^{20} \mathrm{~J}$. Loeb, The mechanistic conception of life, edited by D. Fleming, Cambridge, Mass., Harvard University Press, 1964.

${ }^{21} \mathrm{~L}$. Loeb, 'On certain activities of the epithelial tissue of the skin of the guinea-pig, and similar occurrences in tumors', Bull. Johns Hopk. Hosp., 1898, 9: 1-5, p. 2.
} 


\section{Experimental pathology and the origins of tissue culture}

seems probable that Ribbert's ideas on the similarities between cell behaviour in normal regenerating tissue and in a growing tumour guided Loeb's approach.

Although Loeb referred to inducing cell movement by "... removing tension on one side", he referred to Weigert and not Ribbert. ${ }^{22}$ But he did offer observations indicating that physical separation of cells could occur during normal regeneration: "The activity of the epithelial tissue goes further than merely to migrate. It can and in most cases does actually penetrate into the blood-clot, occasionally into the connective tissue". ${ }^{23}$ Loeb further emphasized the importance of cell movement by citing work on sea urchins by Hans Driesch ${ }^{24}$ and pointing out how migrating mesenchyme cells in the sea urchin and epithelial cells in skin regeneration had a characteristic elongated shape that was also a feature of cancer cells. ${ }^{25}$

Loeb then turned to transplantation experiments to pursue his investigations of tumour growth. The first tumour transplantation experiments may have been performed as early as 1868 , but by 1900 this area of research was in disarray. In a review published in 1900, Sailer commented: "The number of experiments of this nature [transplantation] is now very considerable, and the results are astoundingly at variance". ${ }^{26}$ Loeb, and later Jensen, ${ }^{27}$ were so successful at resolving these inconsistencies and establishing tumour transplantation as a major experimental technique in cancer research that in 1907 Ewing wrote: "The results already obtained in this field are of such fundamental importance as to lead some to express the belief that the beginning of the end of the cancer problem is in sight". ${ }^{28}$

In his first paper on tumour transplantation, ${ }^{29}$ Loeb described transplanting some 360 fragments of a rat thyroid sarcoma to 150 host animals over a fifteen-month period. He was concerned with the origins of the cells found in the tumours that arose from the transplants, and in one set of experiments he attempted to distinguish absolutely between transplant and host by isolating the tumour fragments in gauze bags, but obtained variable results. ${ }^{30}$ Loeb also attempted to determine if transplanted sarcoma cells behaved towards foreign bodies in the same way as normal connective tissue cells, by implanting threads of cotton or silk or pieces of agar along with the tumour. He observed invasion of the agar by both normal and sarcoma cells, and both types of cell behaved similarly. ${ }^{31} \mathrm{He}$ did not say whether his observations of cells penetrating blood clots in wound healing suggested the use of agar, but it was a medium he continued to use.

\footnotetext{
22 Ibid., p. 1.

${ }^{23}$ Ibid., p. 2.

${ }^{24}$ For a discussion of Driesch's work see F. B. Churchill, 'From machine-theory to entelechy: two studies in developmental teleology', J. Hist. Biol., 1968, 1: 91-112.

${ }^{25}$ Loeb, op. cit., note 21 above, pp. 2-3.

${ }^{26} \mathrm{~J}$. Sailer, 'A critical summary of the literature on the inoculability of carcinoma', Am. J. med. Sci., 1900, 120: 190-202, p. 190. Sailer remarked of one paper that it was "written so carelessly" and "the details are so meagre and unsatisfactory that ... it can, I think, be entirely disregarded". Ibid., p. 198.

${ }^{27}$ Triolo suggests that Jensen's work was “... the actual starting point for most of the experimental mouse tumor research in Europe and the United States". Triolo (1964), op. cit., note 11 above, p. 10.

28 Ewing, op. cit., note 11 above, p. 64.

${ }^{29}$ L. Loeb, 'On transplantation of tumors', J. med. Res., 1901, 6: 28-38.

${ }^{30}$ Ibid., p. 30.

31 Ibid., p. 32.
} 


\section{Jan A. Witkowski}

In the same year (1901), Loeb described a series of experiments designed to separate epithelial cells from connective tissue in a regenerating wound, and he employed two techniques to do so. The first was similar to that just described: a small piece of skin was raised in the ear of a guinea-pig and the cartilage underlying the skin flap was replaced by a small piece of agar. Loeb found that the agar was invaded by leucocytes and epithelium in much the same way as a blood clot was invaded. ${ }^{32} \mathrm{His}$ second method was more interesting: "A piece of the tissue, in this case of epithelium of the skin, is entirely cut off with a razor and pushed into coagulated blood serum as it is used for bacteriological purposes. The blood serum with the included epithelium is transferred afterwards into a living animal". ${ }^{33}$ When the blood clots were examined after seven to ten days Loeb found that the epithelium continued to grow and that occasionally there were single cells detached from the main mass of cells. I call this Loeb's "implant" technique, and he hoped that it would provide the means to investigate tissue growth "under variable conditions". ${ }^{34}$

Loeb published a further paper on tumour transplantation in 1902, in which he again attempted to determine the origins of the cells found at the periphery of a transplanted tumour by comparing them with the cells that invaded agar pieces. He found only leucocytes and connective tissue cells in the agar, and concluded that the cells present in the periphery of the transplanted tumour were derived from the tumour and not from the host. ${ }^{35}$

The "implant" technique was further exploited as a model system for studying cancer by showing "that in epithelium growing in blood-serum in a guinea-pig certain features are produced of interest to the interpretation of some structural peculiarities found in carcinoma". ${ }^{36}$ However, even though the epithelium in the blood-clot was isolated and free from tissue tension, it showed only limited growth and the cells never multiplied rapidly as in a carcinoma. ${ }^{37}$ Ribbert's "tissue tension" theory could not be wholly correct, and "some special chemical or physico-chemical conditions must be present" to bring about continuous growth. Nevertheless, Loeb believed that there were some similarities between the behaviour of the implanted epithelium and malignant tumours.

In 1903, Loeb discussed at length the relationship between embryological research and cancer research, and reviewed the relevant experimental data. This paper is important because it makes explicit the embryological background of Loeb's approach to cancer research and his commitment to experimental analysis. Loeb began by commenting that: "In explaining malignant tumours pathologists have made use of two of the most obvious instances of ordinary tissue growth, namely, embryonic development and regenerative phenomena". ${ }^{38} \mathrm{He}$ summarized Cohnheim's and Rib-

${ }^{32}$ L. Loeb, 'On the growth of epithelium', J. Am. Med. Assoc., 1901, 37: 1024-1025, p. 1024.

${ }^{33}$ Ibid.

${ }^{34}$ Ibid.

${ }^{35}$ L. Loeb, 'Further investigations in transplantation of tumors', J. med. Res., 1902, 8: 44-73, p. 52.

${ }^{36} \mathrm{~L}$. Loeb, 'On the growth of epithelium in agar and blood-serum in the living body', ibid., 1902, 8: 109-115, p. 109.

${ }^{37}$ Ibid.

${ }^{38}$ L. Loeb, 'Cell implantation in the production of tumors', J. Am. Med. Assoc., 1903, 40: 974-977, p. 974. 


\section{Experimental pathology and the origins of tissue culture}

bert's theories, and examined experimental results in relation to two questions: first, “... how do displaced embryonic cells actually behave?". Loeb discussed experiments in which early embryos were manipulated so that blastomeres came to be displaced from their normal positions, or were entirely separated from each other, or were transplanted to adult animals. Loeb was clearly unimpressed by the support these experiments gave to either Cohnheim or Ribbert, although he rather grudgingly conceded that teratomas might arise from isolated blastomeres. ${ }^{39}$

Loeb then turned to his second question: “... can malignant tumors be explained by the detachment of cells, embryonic or adult?". ${ }^{40}$ Comparison of transplanted tumour cells with transplanted normal embryonic or adult cells showed that the differences in growth between these types of cell “... is very striking"; so striking that Loeb concluded: "The theories based on the supposition of detached, either embryonic or adult cells, as the cause of tumors, are at the present state of our knowledge not sufficient to explain the growth of malignant tumors". ${ }^{41}$ These theories were based on the principle enunciated by Weigert, that "All cell growth is caused by removing the tension of the neighbouring cells". ${ }^{42}$ This principle was based on deductive, $a$ priori reasoning and for Ribbert the term "tissue tension" no longer implied mechanical tension and mutual restraint by cells, but it could also mean any change in a chemical or physical sense. It had become so general in its meaning that it had lost its value and become "metaphorical". Loeb rejected this approach. For him, "... an analysis, and especially an experimental one, of the facts of embryonic development and of the regenerative processes" 43 was much more promising than abstract discussion of Weigert's principle. This declaration of Loeb's faith in the application of experimental analysis to pathological problems clearly echoes the stance taken by the experimental embryologists.

\section{LOEB'S RESEARCH 1910-1920}

Loeb published many papers between 1903 and 1910, but none of these described any further applications or development of the implant technique. However, between 1910 and 1920, Loeb returned to this type of study and in a series of papers he compared his implant technique in animals with "true" tissue culture. The results of his tissue culture experiments are not relevant here, but the claims Loeb made are important in trying to understand the contributions he thought his pathological work had made to tissue culture.

\footnotetext{
39 Ibid., p. 975.

40 Ibid.

41 Ibid., p. 976.

42 Ibid.

${ }^{43}$ Ibid., p. 977. The importance of Loeb's insistence on experimentation in cancer research was recognized by Ewing in his Harvey Lecture of 1909 . Commenting on Loeb's transplant experiments and his attempts to modify tumour growth by using potassium cyanide or high temperatures $\left(43^{\circ} \mathrm{C}\right)$, Ewing wrote: "Even more important [than the results themselves] was the demonstration of the value of the experimental method in the study of the general problems of tumor growth". Ewing, op. cit., note 11 above, p. 66. The experiments of Loeb referred to were reported in L. Loeb, 'On some conditions determining variations in the energy of tumor growth', Am. Med., 1905, 10: 265-269, p. 268.
} 


\section{Jan A. Witkowski}

In 1910, Loeb and M. S. Fleisher published a short note entitled 'The relative importance of stroma and parenchyma in the growth of certain organs in culture media'. ${ }^{44}$ They referred to the "most interesting experiments" of Harrison, and it is probable that it was the success of Harrison and the exploitation of his method by Carrel that induced Loeb to take up these experiments again after a gap of eight years.

In this paper, Loeb made certain claims for his implant technique that he was to repeat with slight variations in all his tissue culture publications. First, he referred to his observations "of about fifteen years ago" that cells could grow into a blood clot. These suggested to him that "it might be possible to make various tissues grow in culture media outside of the body, in the thermostat, as well as inside the body, in the latter case the body acting as a thermostat". ${ }^{45}$ At that time, Loeb pursued this idea and "At first he carried out experiments in vitro as well as experiments in which the animal body acted as an incubator". ${ }^{46}$ "Lack of the necessary facilities made it very soon necessary for him to limit himself to the latter kinds of experiments [using animals]". Nevertheless, "To our knowledge in these our earlier experiments for the first time the attempt was recorded in the literature to grow tissues of higher animals under artificial conditions in environments that differ from those found in the body under natural conditions". ${ }^{47}$

These claims were repeated in 1911 in a brief note in Science, ${ }^{48}$ and this paper also illustrates a confusion that can arise when attempting to disentangle Loeb's culture work; it is often not clear if he is referring to studies done using tissues embedded in agar and implanted in animals, or incubated in vitro in a test-tube. The work reported in this Science note was described in Loeb's contribution to a symposium on tissue culture held in December 1911. Loeb again made the claims listed above; his original observations suggested that it should be possible to "cultivate tissues on solid culture media in the test tube as well as within the body", ${ }^{49}$ and that "Experiments were accordingly undertaken by me in vitro - using coagulated blood-serum, blood-clot and agar as culture media, as well as in vivo".so Again, Loeb's indiscriminate use of "culture medium" to refer to both the blood clot used in the implant method and the plasma clot used in vitro makes it difficult to distinguish which method was used when.

At the 1913 Congress of American Physicians and Surgeons, Loeb commented on the paper delivered by R. A. Lambert, ${ }^{51}$ contrasting his own method with the Harrison technique. Loeb's method involved the insertion of larger pieces of tissue in "culture

\footnotetext{
44 M. S. Fleisher and L. Loeb, 'The relative importance of stroma and parenchyma in the growth of certain organs in culture media', Proc. Soc. Exp. Biol. Med., 1910, 8: 133-138.

${ }^{45}$ Ibid., p. 134.

46 Ibid.

47 Ibid.

${ }^{48} \mathrm{~L}$. Loeb, 'On some conditions of tissue growth, especially in culture media', Science, 1911, 34: 414-415.

$4 \mathrm{~L}$. Loeb, 'Growth of tissues in culture media and its significance for the analysis of growth phenomena', Anat. Rec., 1912, 6: 109-120, p. 109.

so Ibid., p. 110.

${ }^{31}$ R. A. Lambert, 'The life of tissues outside the organism from the pathological standpoint', Trans. Congr. Am. Physns. Surg., 1913, 9: 91-104. Loeb's comments will be found on pp. 99-101.
} 


\section{Experimental pathology and the origins of tissue culture}

media in the test-tube" than was used in cover-slip cultures. This method was more tedious, but it had certain advantages, particularly in being able to study the behaviour of cells within the explant rather than just at the thin outgrowth of cells on a cover-slip.

During this period, Loeb had been collaborating with M. S. Fleisher, and in a paper published in 1917 they examined the movements of cells in vitro, in relation to stereotropism. Loeb also described the sequence of research he had followed: (i) studies of cell movement in wounds and in blood clots; (ii) "the cultivation of tissues in various coagula in the test tube"; (iii) implantation of tissues using "the living body of a guinea-pig as a thermostat". ${ }^{52}$ This paper dealt principally with cell movement, but Loeb and Fleisher were also concerned with tissue growth and intended to present "... an analysis of the factors determining that aspect of growth of various tissues which consist in cell or tissue movements". ${ }^{33}$ These interests seem derived from Loeb's earlier concern with the problem of cell displacement and the loss of tissue tension, but in this paper the phenomenon of cell movement in various media under different conditions was examined for its own interest.

Loeb and Fleisher turned to a study of cell division in vitro in their next paper ${ }^{54}$ and Loeb again referred to his test-tube experiments as being the same in principle as those "first described by one of us in 1897". ${ }^{35}$ They intended to compare the growth of regenerating kidney with normal kidney, and to determine what effects agents such as oxygen, potassium cyanide, and micro-organisms had on cell growth. One series of experiments is of particular interest in relation to Loeb's earlier implant experiments. In this series, Loeb and Fleisher compared the growth of regenerating rabbit kidney with that of a mouse carcinoma and found that both types of tissue behaved similarly. Loeb's views of the relationship between transplantation and in vitro tissue culture is illustrated by the conclusion to this paper: "... tissues after transplantation into culture media in vitro behave in all essential respects in a manner similar to tissues transplanted into the subcutaneous tissue in the living animal"; 36 the two methods were identical in principle and in results. This appears to have been Loeb's last publication dealing specifically with tissue culture.

\section{HARRISON, EXPERIMENTAL EMBR YOLOGY, AND TISSUE CULTURE}

The relationship between Harrison's background in experimental embryology and his development of tissue culture has been explored thoroughly by Oppenheimer, ${ }^{37}$ and I shall discuss this background only to draw attention to similarities between Harrison's and Loeb's experimental work.

${ }^{52} \mathrm{~L}$. Loeb and M. S. Fleisher, 'On the factors which determine the movements of tissues in culture media', J. med. Res., 1917, 37: 75-99, pp. 75-76.

s3 Ibid., p. 77.

${ }^{54} \mathrm{~L}$. Loeb and M. S. Fleisher, 'The growth of tissues in the test-tube under experimentally varied conditions with special reference to mitotic cell proliferation', J. med. Res., 1919, 40: 509-550.

ss Ibid., p. 509.

s6 Ibid., p. 535.

${ }^{57}$ Oppenheimer, op. cit., notes 3 and 4 above. See also V. Hamburger, 'S. Ramon y Cajal, R. G. Harrison and the beginnings of neurobiology', Pers. Biol. Med., 1980, 23: 600-616. 


\section{Jan A. Witkowski}

Harrison's development of tissue culture was the logical outcome of his extensive studies of the development of peripheral nerves during embryogenesis. ${ }^{38}$ At the time Harrison began this work, there were three main theories ${ }^{59}$ that attempted to account for nerve development: (i) The cytoplasmic bridge theory of Hensen ${ }^{60}$ proposed that the cells of the embryo were linked together by fine strands of cytoplasm that developed into nerves, the pattern of nerve development depending on the activity of the peripheral tissues. (ii) The nerve outgrowth theory of $\mathrm{His}^{61}$ and Ramon y Cajal ${ }^{62}$ considered all nerve fibres to be outgrowths from ganglia or spinal cord. (iii) In that proposed by Schwann ${ }^{63}$ and elaborated by Balfour, ${ }^{64}$ the nerve fibres were thought to be secreted by the Schwann cells in the periphery and the glial cells in the central nervous system.

Harrison's interest in this problem was manifest in his first major experimental paper published in 1898. Harrison intended to "... trace out the modes of growth of individual structures or organs"6s and to do this he exploited Born's discovery that parts of amphibian embryos could be fused together ${ }^{66}$ By transplanting the tails of 2to 7-mm. embryos, Harrison observed that there was a shifting of the epidermis from the trunk to the grafted tail as the latter elongated during growth. He commented that this was a "most interesting phenomenon when considered in connection with the mode of distribution of the cutaneous nerves in the adult vertebrate"; $;$ the movements of the epidermis observed experimentally corresponded to the displacement of the sensory nerves. Harrison remarked that his results should not be construed "as necessarily contradicting the view, almost generally accepted" that a nerve fibre grew out from the ganglion, ${ }^{68}$ indicating that as early as 1898 he favoured the His-Cajal

\footnotetext{
38 Harrison reviewed this work in his Harvey and Croonian lectures of 1908 and 1933 respectively. R. G. Harrison, 'Embryonic transplantation and development of the nervous system', Anat. Rec., 1908, 2: 385-410; idem, 'On the origin and development of the nervous system studied by the methods of experimental embryology', Proc. R. Soc. Lond., 1935, 118: 155-196. The latter was reprinted with additional notes and illustrations in S. Wilens (editor), Organization and development of the embryo, New Haven, Conn., Yale University Press, 1969, pp. 117-165.

39 S. M. Billings, 'Concepts of nerve development, 1839-1930', J. Hist. Biol., 1971, 4: 275-305.

${ }^{\circ} \mathrm{V}$. Hensen, 'Ueber die Entwicklung des Gewebes und der Nerven im Schwanze der Froschlarve', Virchows Arch. Path. Anat., 1864, 31: 51-73.

61 W. His, 'Zur Geschichte des menschlichen Rückenmarks und der Nervenwurzeln', Abh. math-phy. Cl. Konigl. Sachsischen Ges. Wiss. (Lpz.), 1886, 13: 479-513.

${ }_{62} \mathrm{~S}$. Ramon y Cajal, 'A quelle époque apparaissent les expansions des cellules nerveuses de la moëlle épinière du poulet?', Anat. Anz., 1890, 5: 609-613 and 631-639.

${ }^{63}$ T. Schwann, Mikroskopische Untersuchungen über die Uebereinstimmung in der Struktur und dem Wachsthum der Thiere und Planzen, Berlin, Sanders, 1839.

${ }^{64} \mathrm{~F}$. Balfour, 'On the development of the spinal nerves in elasmobranch fishes', Phil. Trans. R. Soc. Lond., 1876, 166: 175-195.

cs R. G. Harrison, 'The growth and regeneration of the tail of the frog larva', Bull. Johns Hopk. Hosp., 1898, 10: 173-194, p. 173.

66 Gustav Born, in the course of surgical experiments on frog larvae, had left several operated embryos in the same dish and was astonished to find the next morning that separate fragments of embryo had fused together. Oppenheimer has discussed Born's discovery and Harrison's exploitation of it (Oppenheimer (1971), op. cit., note 4 above). Harrison later used the technique to carry out studies of growth: R. G. Harrison, 'Hetero-plastic grafting in embryology', Harvey Lect., 1933-1934, 116-157. Reprinted with additional illustrations and notes in Wilens (editor), op. cit., note 58 above, pp. 215-257.
}

${ }^{67}$ Harrison, op. cit., note 65 above, p. 178.

as Ibid., footnote. 
theory.

The question of how the nerve fibre grew out from the ganglion could not be answered by the histological preparations of Cajal and Held, superb though these were. The ultimate failure of histology was demonstrated by Cajal's astonishment, on examining Held's preparations, that they could disagree on interpretation when the preparations were so similar. ${ }^{69}$ Harrison himself wrote: "When one compares the careful analyses of their observations [on nerve development in normal embryos], as given by various authors, one cannot but be convinced of the futility of trying by this method to satisfy everyone that any particular view is correct". ${ }^{70} \mathrm{~A}$ fresh approach was required, and "The only hope of settling these problems definitely lies, therefore, in experimentation"."

Harrison began by determining if the Schwann cells were essential for nerve development. He removed the neural crest from young (2- to 7-mm.) frog embryos, depriving the embryos of both Schwann cells and spinal ganglia. The embryos that developed lacked entirely sensory nerves and Schwann cells, but motor nerves were present. If the ventral half of the neural tube was removed, the resulting embryos were paralysed, and histological examination showed that while sensory nerves and Schwann cells were present, motor nerves were totally absent. ${ }^{72}$

Having determined that Schwann cells were not necessary for motor nerve development, Harrison turned to the problem of how the connexion between nerve cell body and end organ arises. The importance of this set of experiments is two-fold; some experiments resemble very closely the kind performed by Loeb, and they also led Harrison directly to tissue culture. Harrison's strategy was to alter in various ways the environment in which the nerve fibres develop. If there were preformed structures in the tissues that contributed to the formation of nerve fibres, then any disturbance of a tissue before nerves appeared in it should lead to the absence of nerve. If nerves were able to grow in altered surroundings, the results would be strong support for the His-Cajal outgrowth theory.

Harrison had shown by removing the medullary cord in the trunk region that "... when the nerve centers of a given region are removed before differentiation of peripheral nerves has begun, no nerves develop in that region". ${ }^{73}$ However, histological examination revealed that nerve fibres had grown out from the brain into the mesenchyme tissue that filled the space left by removal of the cord, ". . . a tissue, as

\footnotetext{
${ }^{69} \mathrm{~S}$. Ramon y Cajal, 'Nouvelles observations sur l'évolution der neuroblastes avec quelques remarques sur l'hypothèse neurogénétique de Hensen-Held', Anat. Anz., 1908, 32: 1-25 and 65-87, p. 3, footnote.

${ }^{70}$ R. G. Harrison, 'Further experiments on the development of peripheral nerves', Am. J. Anat., 1906, 5: 121-131, p. 121.

$"$ Ibid.

72 These experiments were first performed during the course of a study of the effects of innervation on muscle development; R. G. Harrison, 'An experimental study of the relation of the nervous system to the developing musculature of the frog', Am. J. Anat., 1904, 3: 197-220. Harrison gave more extended descriptions of these experiments later, particularly in his Harvey lecture of 1908 . Harrison, op. cit., note 58 above, and in R. G. Harrison, 'The development of peripheral nerve fibers in altered surroundings', Arch. EntwMech. Org., 1910, 30: 15-30. Harrison's final paper on the role of the Schwann cell in nerve development was not published until twenty years after his first paper on the subject. R. G. Harrison, 'Neuroblast versus sheath cell in the development of peripheral nerves', J. comp. Neurol., 1924, 37: 123-205.

${ }^{73}$ Harrison (1910), op. cit., note 72 above, p. 20.
} 


\section{Jan A. Witkowski}

unlike that forming the normal path [of nerve fibre growth] as it could possibly be". ${ }^{74}$ Even more unlikely surroundings were provided by first denervating embryos, and then transplanting fragments of neural tube to pockets formed in the epidermis of the abdomen. Typical peripheral nerves grew out from the fragments, and in one remarkable case nerve fibres were found running free across the peritoneal cavity. ${ }^{75}$ Those results led Harrison to declare decisively in favour of the view that the nerve fibre is "the outgrowth of a single ganglion cell, with which it remains in continuity throughout its life". ${ }^{76}$ The technique used in these latter experiments closely resembles that used by Loeb in those experiments in which he observed cells penetrating blood clots and those in which he transplanted fragments of tumour.

Further parallels between Harrison's and Loeb's experimental methods are evident in Harrison's next set of experiments. Here, altered surroundings for nerve growth were provided by replacing sections of neural tube with cylindrical blood clots formed by drawing adult frog blood into capillary tubing. Harrison found that nerve fibres penetrated the clot, for as long as $120 \mu \mathrm{m}$. and $170 \mu \mathrm{m}$. ${ }^{n}$ There could be no intercellular bridges in a blood clot where there were no cells, and Harrison concluded that "... these experiments must be regarded as decisive against the protoplasmic bridge theory". ${ }^{78}$ The similarity of these experiments to those of Loeb is striking. Loeb had originally observed cells moving into a blood clot during wound healing and later used a block of agar implanted in an animal to determine what cells were able to penetrate it. Harrison had first observed nerve fibres penetrating unusual tissues and then used a clot of blood. Although Harrison's paper was well documented, he did not refer to Loeb. Harrison later referred to the experiments with cylindrical blood clots as being a link between his transplantation and in vitro experiments, but it is very unlikely that he progressed smoothly from one method to the next. These experiments were carried on at the same time as Harrison's attempts at tissue culture in vitro, and it is clear that they were rendered redundant by his success with in vitro culture. ${ }^{99}$ Both sets of experiments were performed because in the earlier experiments "... nerve fibres had developed in surroundings composed of living organized tissues" that might have contributed "organized material" to the nerve fibres. ${ }^{80}$ "The crucial experiment remained to be performed and that was to test the power of the nerve centers to form nerve fibres within some foreign medium, which could not by any possibility be suspected of contributing organized protoplasm to them". 81

Harrison's crucial and successful experiment was to explant fragments of neural

74 Harrison, op. cit., note 70 above, p. 129.

${ }^{75}$ Harrison (1910), op. cit., note 72 above, pp. 25-27.

${ }^{76}$ Harrison, op. cit., note 70 above, p. 131.

7 Harrison (1910), op. cit., note 72 above, pp. 28-30.

78 Ibid., p. 30.

79 "Although the experiments here described may, therefore, seem to be somewhat overshadowed in significance they nevertheless form an essential link in the chain of evidence, leading to the establishment of the outgrowth theory." Harrison asked to be "pardoned" for the "rather belated appearance" of the report. Ibid., p. 16.

${ }^{80}$ R. G. Harrison, 'The outgrowth of the nerve fiber as a mode of proto-plasmic movement', J. exp. Zool., 1910, 9: 787-846, p. 790.

81 Ibid. 


\section{Experimental pathology and the origins of tissue culture}

tube in clots of lymph in hanging drop cultures in vitro, but these were not his first attempts at in vitro culture. In his major paper on tissue culture he referred to placing fragments of tissue in physiological saline, but these were unsuccessful. "Later a more natural environment for the isolated tissue was sought in the ventricles of the brain and in the pharynx of young embryos", but these were also unsuccessful. ${ }^{82}$ However, where fragments of tissue became attached to tissue in the embryo, nerve fibres grew out and Harrison concluded that nerve fibres were probably "stereotropic", unable to grow out into a liquid medium.$^{83}$ These experiments resemble closely those of Loeb. In both cases, the investigators attempted to exploit the natural conditions within the body as an artificial environment in which to grow tissues. Loeb, indeed, was more successful. He had recognized "stereotropism" in 1898, and it was for this reason that he embedded tissue in agar before implantation. In his in vitro technique, Harrison used gelatine and lymph clots, but there is no evidence to suggest that he tried implanting embedded tissues into an embryo.

Harrison later used tissue culture to investigate stereotropism, and this was the basis of his last experimental paper on tissue culture ${ }^{85}$ His interests turned to studies of polarity in the developing embryo, ${ }^{86}$ but he published several reviews discussing tissue culture that I shall refer to when comparing his achievements with those of Loeb.

\section{LOEB'S CONTRIBUTIONS TO TISSUE CULTURE}

If experimental pathology, and in particular Loeb's work, was a significant factor in the development of tissue culture, it is important to determine what Loeb himself thought were the important features of his work and whether the claims he made for it were justified. The most important of these claims were that: (i) he had recognized the "general principles" and importance of growing cells in an artificial environment; (ii) his work using tissues embedded in agar or plasma clots and implanted in animals was the first attempt recorded in the literature to grow tissues of higher animals under artificial conditions in "environments that differ from those found in the body under natural conditions"; ${ }^{87}$ and (iii) that at some time (prior to 1897) he had obtained similar results with tissues embedded in agar in test-tubes.

It is clear that Loeb recognized that it would be a considerable advance if it was possible to study cells in isolation: "The possibility of separating the growing epithelium from other tissues might be used to subject an isolated tissue like epithelium to certain experimental conditions, as for instance, to the influence of

82 Ibid., p. 799.

83 Ibid., p. 800.

${ }^{84}$ Loeb, op. cit., note 21 above, p. 3-4.

ss R. G. Harrison, 'The reaction of embryonic cells to solid structures', J. exp. Zool., 1914, 17: 521-544. In a remarkable tour de force, Harrison used spiders' webs to study the contact guidance of cells.

${ }^{86}$ R. G. Harrison, 'Relations of symmetry in the developing embryo', Collecting Net, 1936, 11: 217-226. Reprinted with additional notes and illustrations in Wilens (editor), op. cit., note 58 above, pp. 166-214; J. A. Witkowski, 'R. G. Harrison and W. T. Astbury: the search for the molecular basis of the determination of form in the developing embryo', Notes Rec. R. Soc. Lond., 1980, 35: 195-219.

${ }^{87}$ Fleisher and Loeb, op. cit., note 44 above. 
different chemical substances and thus study the reaction of isolated tissues, other than connective tissue and leucocytes to different stimuli." 88

However, the method Loeb employed of using animal bodies as incubators for implanted tissue was not capable of being used in the manner he proposed. The tissue in agar was isolated, but it was impossible for the chemical environment to be controlled or manipulated, and Loeb did not publish the results of experiments in which he used the implant method in this way. I do not think it can be claimed that he recognized the "general principles" of tissue culture, beyond realizing the need for the tissue to be isolated and kept at body temperature. He does not seem to have considered the problem of cell nutrition.

Loeb's second claim was made in papers dealing with tissue culture in the sense used by Harrison, Carrel, and the Lewises, and he must have intended his readers to assess his claim in that context. However, it is a claim of so general a nature that it encompasses almost any circumstance, and the examples listed by Oppenheimer ${ }^{89}$ and Rubin $^{90}$ are other examples where cells and tissues were kept in unnatural environments. Tissue culture was understood from its inception to be an in vitro technique, and Loeb's implant method must be regarded as a special form of in vivo technique.

Loeb's claim to have obtained in vitro cultures in test-tubes refers to a paper published in 1897 . This was a monograph that he had printed privately in Chicago, ${ }^{91}$ and, while it refers to this method, no details of technique or results are given. There is no good evidence to support this claim, and it is clear from Loeb's own writings that he had very little success with test-tube cultures prior to 1911 . He referred to the difficulties he had had with this approach, ${ }^{92}$ and it was probably for this reason that he turned to transplantation and what I have called his implant technique. Although Rubin suggests that Loeb outlined "the optimal conditions for in vitro growth", ${ }^{33}$ it is difficult to understand how he could have done so when he was so unsuccessful.

\section{CONTEMPORARY OPINIONS OF LOEB'S WORK}

With hindsight, it appears that Loeb's in vitro work prior to 1911 was a failure, but this may be misleading. Although he did not achieve in vitro culture, his views and comments may have influenced his contemporaries and helped prepare for Harrison's work. Is there any evidence to suggest that this might be so?

The most important of Loeb's contemporaries in tissue culture was undoubtedly Alexis Carrel, whose work at the Rockefeller Institute stimulated research in tissue culture throughout the world. ${ }^{94}$ Carrel's assistant Montrose Burrows spent the spring of 1910 in Harrison's laboratory, and made a major technical advance when he found

\footnotetext{
Loeb, op. cit., note 32 above, p. 1025.

"Oppenheimer, op. cit., note 4 above.

${ }^{90}$ Rubin, op. cit., note 4 above.

${ }^{91}$ L. Loeb, Ueber die Entstehung von Bindegewebe, Leucocyten und roten Blutkörperchen aus Epithel und über eine Methode, isolierte Gewebsteile zu züchten, Chicago, M. Stern, 1897.

92 For example, "Lack of the necessary facilities made it very soon necessary for him to limit himself to the latter kinds of experiments [using animals]", Fleisher and Loeb, op. cit., note 44 above.

${ }_{93}$ Rubin, op. cit., note 4 above, p. 45.

94 J. A. Witkowski, 'Alexis Carrel and the mysticism of tissue culture', Med. Hist., 1979, 23: 279-296.
} 


\section{Experimental pathology and the origins of tissue culture}

plasma could be used in place of lymph as a clot for embedding tissue. On his return to the Rockefeller Institute, Burrows and Carrel began an intensive tissue culture programme and presented a series of papers in Paris in November and December 1910. Although Harrison does not appear as an author, he was fully credited by Burrows and Carrel as the originator of the technique, ${ }^{95}$ and three papers that Burrows published under his name alone gave Harrison's laboratory as his address.96 Carrel and Burrows did not recognize any contribution by Loeb. In 1911, they wrote, "Although thirteen years have elapsed since his announcement, he has not yet given the results and the techniques of his method of cultivation of tissues outside of the body". ${ }^{97}$ They described his implant experiments but commented that "they cannot be considered as being strictly equivalent to a culture". ${ }^{98}$

Another major line of tissue culture development was followed by Margaret and Warren Lewis who were interested in the morphology and differentiation of cells in vitro. ${ }^{99}$ Following the publication of Burrows' work, the Lewises were encouraged to take up cell culture, but, in fact, they had already made some attempts at in vitro culture before 1910. Margaret Lewis's (then Margaret Reed) interest in in vitro studies had been stimulated by her studies with M. Hartman in Berlin in 1908. Like Loeb, Margaret Lewis also used nutrient agar as a substratum for cell movement, and she found that guinea-pig bone marrow cells grew out over the surface of the agar, and she had observed dividing cells. ${ }^{100}$ However, the Lewises did not acknowledge any contribution from Loeb.

Smyth, who wrote an early review of tissue culture in 1914, devoted his opening paragraph to Loeb's implant technique. He recognized that Loeb had obtained cell growth into blocks of agar, but he contrasted this use of an animal as an incubator with "the first reports of the cultivation of animal tissues outside of the body" that were "made by Ross G. Harrison in 1907 and again in 1910"101 (my italics). Meltzer, in his review published in 1912, repeated Loeb's claims that he had cultivated tissue in vitro before 1897, and wrote that it was a "misapprehension of the facts of the case" that Loeb had performed only implant experiments: "It can be safely claimed that Loeb was the first investigator who conceived the ingenious plan of cultivating tissues

\footnotetext{
95 "The starting point of our researches was the beautiful work of Harrison on the embryonic tissues of the frog." A. Carrel and M. T. Burrows, 'Cultivation of adult tissues and organs outside of the body', $J$. Am. Med. Assoc., 1910, 55: 1379-1381, p. 1379.

${ }^{96} \mathrm{M}$. T. Burrows, 'The cultivation of tissues of the chick embryo outside the body', ibid., 1910, 55: 2057-2058: idem, 'Cultures des tissus d'embryon de poulet et spécialement cultures de nerfs poulets en dehors de l'organisme', C.r. Soc. Biol. Paris, 1910, 69: 291-292; idem, 'The growth of tissues of the chick embryo outside the animal body, with special reference to the nervous system', J. exp. Zool., 1911, 10: 63-84.

${ }^{97}$ A. Carrel and M. T. Burrows, 'Cultivation of tissues in vitro and its technique', J. exp. Med., 1911, 13: 387-396, p. 388.

98 Ibid.

99 The fruitful results of this approach were reviewed by W. H. Lewis and M. R. Lewis, 'Behavior of cells in tissue culture', in E. V. Cowdry (editor), General cytology, pp. 383-447, Chicago, University of Chicago Press, 1924. A biography of W. H. Lewis is given by G. W. Corner, 'Warren Harmon Lewis, 1870-1964', Biogr. Mem. Natl. Acad. Sci., 1967, 39: 323-358.

${ }_{100}$ M. R. Lewis and W. H. Lewis, 'The growth of embryonic chick tissues in artificial media, agar and bouillon', Bull. Johns Hopk. Hosp., 1911, 22: 126-127.

${ }^{101}$ Smyth, op. cit., note 2 above.
} 


\section{Jan A. Witkowski}

in media outside of the body". ${ }^{102}$ As Oppenheimer and Rubin have shown, this is not true, as was recognized by Fischer in his monograph on tissue culture where he referred to the work of Cohnheim and Maximoff. While Fischer acknowledged the success of Loeb's implant technique, he was sceptical of Loeb's other claims and pointed out that the description of Loeb's in vitro technique had not been published. ${ }^{103}$

A particularly perceptive review of the history of tissue culture was published by Emile Craciun in 1931. He contrasted the static observations of classical histology with methods that permitted study of the dynamic functioning of living animals, and referred to the general principles that had been gradually recognized as essential if tissues were to be grown isolated from the body. Craciun discussed Loeb's work in detail, and thought that Loeb had established three important requirements for studying isolated tissues: "La nécessité de l'asepsie, de la température normale et d'un milieu de culture qui provoque des tropsimes cellulaire positifs, avec, comme résultat, l'invasion du milieu de culture par les cellules . ..". ${ }^{104}$ But Craciun also recognized the limitations of Loeb's approach and wrote that "Ces principes disparates ont été sciemment mis en oeuvre et la technique de cultures de tissus créée par Ross Granville Harrison ...". ${ }^{105}$

There seems to be very little documentary evidence to suggest that Loeb's experiments culturing tissues embedded in agar and implanted in animals had a significant influence on his contemporaries. Those who took up tissue culture as a research tool referred to Harrison's successful technique, or to its modifications by Burrows, Carrel, and the Lewises.

\section{LOEB, HARRISON, AND THE DEVELOPMENT OF TISSUE CULTURE}

It is clear that there were similarities in the techniques used by Loeb and Harrison, and that, although Loeb was not an embryologist, they shared a common background in embryology. Two questions arise. Why, given these similarities, was it Harrison and not Loeb who developed a successful in vitro culture technique? Why did those research workers who took up tissue culture after 1910 ignore or denigrate Loeb's attempts at tissue culture?

There seem to be two answers to the first question, both of which relate to the nature of the problems confronting the two men. First, an in vitro technique was essential for Harrison's work but irrelevant to Loeb's. Although Harrison's in vivo experiments had convinced him that nerve fibres formed by outgrowth from the cell body, the critical experiment necessitated complete isolation of nerve cells. Although he later designed experiments to examine other factors that might influence nerve fibre outgrowth, ${ }^{106}$ he first needed a method by which nerve cells could be studied free of "... the bewildering conditions obtaining within the embryonic body ...". ${ }^{107}$ Loeb's

${ }^{102}$ S. J. Meltzer, 'Cultivation of tissues in vitro', Am. Yr Book, 1912, p. 699-700.

${ }^{103}$ A. Fischer, Tissue culture, Copenhagen, Levin \& Munksgard, 1925.

104 E. C. Craciun, La culture des tissus en biologie expérimentale, Paris, Masson, 1931, p. 8.

105 Ibid., p. 9.

106 Harrison, op. cit., note 85 above.

${ }^{107}$ R. G. Harrison, 'On the status and significance of tissue culture', Arch. exp. Zellforsch., 1928, 6: 4-27, p. 6 . 


\section{Experimental pathology and the origins of tissue culture}

interests were rather different. For him, the ways in which the body reacted to a tumour were of almost equal importance to the growth characteristics of the tumour cells, and he eventually studied a variety of features of the host that affected tumour growth, including the genetic relationship of host and tumour, and the immunological reactions and hormonal states of the host. ${ }^{108}$ There was no incentive for Loeb to persist in developing in vitro techniques that could not be used to study such factors.

Second, the different problems of Loeb and Harrison required quite different methods of observation. The only observation Loeb needed to make was to determine if the transplanted fragment of tumour grew. The cellular behaviour involved did not concern him at this time, and microscopic examination of fixed and embedded material was all that was required to determine the character of the transplanted tumour. In contrast, direct observation of the nerve cell was essential for Harrison. Cajal had observed a "cone of growth" at the ends of nerve fibres in his histological preparations, and postulated that this structure was the means by which a nerve fibre penetrated tissues. ${ }^{109}$ Harrison's analysis of nerve development would have been incomplete if he had not examined critically Cajal's conjecture, and to do so he had "... to obtain a method by which the end of a growing nerve could be brought under direct observation while alive ...". ${ }^{110}$ This could be done only by isolating nerve cells in vitro, and Harrison's descriptions of the structure and behaviour of nerve fibres were convincing demonstrations of the validity of Cajal's views. Particularly striking was the complete identity of the tip of the nerve fibre in vitro with Cajal's "cone of growth" and Billings remarked that "visualization of ... the growth cone was the single most important observation that supported an outgrowth theory". "11 This difference between Loeb's and Harrison's work was remarked on by Harrison and others. Harrison considered the fact that his method enabled living cells to be observed continuously to be one of two "very distinct advantages" of his method."12 Burrows wrote that the "primary object in growing tissue outside the animal body [is] in order that it may be microscopically observed in the living conditions. This object was not possible by Loeb's method which was therefore of little advantage over the study of prepared tissues from the animal body". ${ }^{113}$ This is true but rather unfair in

\footnotetext{
108 In 1910, Loeb wrote, "Experimental investigation permits us, however, not only to analyze the activities of the tumor cells but also the conditions in the host on which in part at least the life of the tumor cells depends" (my italics). L. Loeb, "Recent progress and present status of experimental research in cancer', J. Am. Med. Ass., 1910, 55: 1530-1532. For a discussion of the factors investigated by Loeb, see his autobiography, Loeb, op. cit., note 9 above, pp. 10-13.

${ }^{109}$ Cajal, op. cit., note 62 above. For a discussion of theories accounting for the movement of nerves, see S. E. Black, 'Pseudopods and synapses: the amoeboid theories of neuronal mobility and the early formulation of the synapse concept 1894-1900', Bull. Hist. Med., 1981, 55: 34-58.

${ }^{110}$ R. G. Harrison, 'Observations on the living developing nerve fiber', Proc. Soc. Exp. Biol. Med., 1907, 4: 140-143, pp. 140-141.

111 Billings, op. cit., note 59 above.

112 The other advantage was that the cells were "free from the influences that surround them in the body of the organism". Harrison, op. cit., note 80 above, p. 791.

${ }^{113}$ M. T. Burrows, 'The tissue culture as a physiological method', Trans. Congr. Am. Physns. Surg., 1913, 9: $77-90$, p. 77. Loeb replied that if only the Harrison method of culture was used, “... very important changes that may take place in the transplanted tissues may remain unnoticed, unless we make use of embedding and sectioning the whole tissue". Lambert, op. cit., note 51 above, p. 101.
} 


\section{Jan A. Witkowski}

that this was not Loeb's aim in his experiments.

Turning to the second question, is it possible to identify factors that led to Loeb's contemporaries ignoring his work, and determine those features of Harrison's work that impressed them? There can be no doubt that the major factor was that Harrison was successful; he solved a major problem using a novel technique that was seen immediately to be of very wide application. None of this was true of Loeb's work. Harrison's tissue culture experiments were the logical development of his earlier studies, and this continuity gives Harrison's in vitro work a remarkable feeling of analytical power. ${ }^{114}$ Loeb's bibliography and autobiographical sketch indicate that he studied many problems, and while these centred on cell growth and cell movement, his work appears more fragmentary than Harrison's. Loeb's in vitro methods did not resolve any major problems, while that solved by Harrison was one of the great morphological controversies of the period, and the results would have been of great interest whatever method he had used. The method he did use was revolutionary, and it was realized immediately that it provided an extraordinarily powerful means of studying the dynamic aspects of cell structure and function. Loeb's methods were totally inapplicable to this kind of problem.

Finally, Loeb's in vitro work may have been ignored because, until 1910, few may have known of it. After 1910, when Loeb referred to his earlier work, he cited the monograph he had had privately printed, ${ }^{115}$ but in his papers of 1910,1911 , and 1912 he cited it only as "Chicago 1897". It was listed in the Index Catalogue of the Library of the US Surgeon-General's Office, ${ }^{116}$ but this was in 1913 and it was given only by title and date. One of the more favourable commentaries on Loeb's work came from S. J. Meltzer, but even he concluded that Loeb's in vitro work "was not appreciated and he published his results in a private pamphlet, with the result that it remained practically unknown". ${ }^{117}$ In contrast, Harrison's results were presented at various meetings (in particular his Harvey Lecture of 1908) and published in the leading experimental biology journals.

\section{CONCLUSION}

Loeb claimed priority for the growth of cells in vitro on the basis of unpublished results he alleged to have obtained prior to 1897 . While there is no reason to doubt that he attempted in vitro culture, a critical examination of his published work suggests that he never achieved any real success, and it is unlikely that he outlined "the optimal conditions for in vitro growth". 118 Loeb's implant technique was useful, and acknowledged as such, ${ }^{119}$ in analysing some of the factors involved in tumour growth, and in view of the paucity of worthwhile data obtained by culture of tumour

\footnotetext{
114 Harrison's logical approach has been emphasized by Oppenheimer: "Harrison did not live his intellectual life by hunches; in contrast, he lived by reason and logic, and the inner coherence of his thought was extraordinary". Oppenheimer (1966), op. cit., note 3 above, p. 525.

11 Loeb, op. cit., note 91 above.

116 Index Catalogue of the U.S. Surgeon-General's Office, series 2, 1913, 18: 289-290.

${ }^{117}$ Meltzer, op. cit., note 102 above, p. 699.

118 Rubin, op. cit., note 4 above, p. 45.

19 Carrel and Burrows (op. cit., note 97 above) referred to it as "ingenious".
} 


\section{Experimental pathology and the origins of tissue culture}

cells Loeb was probably wise not to have persisted in attempting in vitro methods. ${ }^{120}$ However, I do not think that this is sufficient to support Rubin's view that experimental pathology (as exemplified by Loeb's work) was, together with experimental embryology, one of "the major avenues to the development and application of tissue culture". ${ }^{121}$ Loeb's contemporaries did not cite his tissue culture work but referred to that of Harrison, and the main threads of tissue culture can be traced back to Harrison. ${ }^{122}$ The available sources demonstrate that Loeb's attempts at tissue culture had little impact on the development or acceptance of the technique, and Loeb made no special claim for this work in his autobiographical sketch. ${ }^{123}$

My analysis of Loeb's and Harrison's work supports Rubin's contention that at the end of the nineteenth century, there was a "relatively high degree of interaction" between experimental pathology and embryology. ${ }^{124}$ This was particularly true of Loeb's own field, oncology, where the theoretical background was largely embryological and there were also similarities in the experimental designs and techniques used by Loeb and Harrison. Why, then, was it Harrison and not Loeb who developed these techniques into tissue culture in vitro? I suggest that the problems facing Harrison and Loeb differed so that only Harrison had to search for such an innovative technique. The lack of impact of Loeb's in vitro work on his contemporaries appears to result from the two factors: Harrison's results were widely broadcast while Loeb's early attempts remained in obscurity, and while Loeb failed to solve any problem, Harrison was extraordinarily successful in solving a major morphological problem. Tissue culture had its roots in experimental embryology, and specifically that practised by Harrison. As Oppenheimer remarked, "... no matter what had been done before his time, and no matter what he did or did not know of it, it was the work of Harrison that began the development of tissue culture as we know it". ${ }^{25}$

${ }^{120}$ In 1916, R. A. Lambert, who was one of the first to make extensive studies of the growth of tumour cells in culture, wrote that "It is possible that a review of the results thus far obtained may prove disappointing". R. A. Lambert, 'Tissue cultures in the investigation of cancer', Am. J. Cancer, 1916, 1: 169-182, p. 170. One of the applications Lambert saw for tissue culture in this field was a study "directed towards the stimulation of normal and tumor cells, when freed from body restraint", an approach derived from Ribbert's tissue tension theory, ibid., p. 179.

121 Rubin, op. cit., note 4 above, p. 34.

122 See, for example, the chart drawn up by Philip White to illustrate the history of tissue culture. P. R. White, The cultivation of animal and plant cells, New York, Ronald Press Company, figure I. It is reproduced in Witkowski, op. cit., note 94 above, figure 2. Although Carrel's laboratory was concerned with cell growth in culture and those who were trained in Carrel's laboratory continued that type of culture (e.g., A. Fischer, R. C. Parker), there is one interesting connexion with organ culture. Dame Honor Fell has drawn attention to the work of D. Thomson, who in 1914 described the maintenance and development of chick limb buds in culture, probably the first attempts at organ culture. Thomson visited Carrel's laboratory in September 1913 to learn tissue culture. H. B. Fell 'Tissue culture and its contribution to biology and medicine', J. exp. Biol., 1972, 57: 1-13, p. 2; D. Thomson 'Some further researches on the cultivation of tissues in vitro', Proc. R. Soc. Med., 1913-1914, 7: 21-46, p. 34; idem, 'Controlled growth en masse (somatic growth)', ibid., 1913-1914, 7: 71-75.

${ }^{123}$ Loeb, op. cit., note 9 above, p. 7.

124 Rubin, op. cit., note 4 above, p. 34.

${ }^{125}$ Oppenheimer (1966), op. cit., note 3 above, p. 534. 


\section{Jan A. Witkowski}

\section{ACKNOWLEDGEMENTS}

I am very grateful to the Wellcome Trust for a generous travel grant that enabled me to study the Harrison papers in the Sterling Library of Yale University, and to Miss Sally Wilens who discussed aspects of Harrison's work with me. 